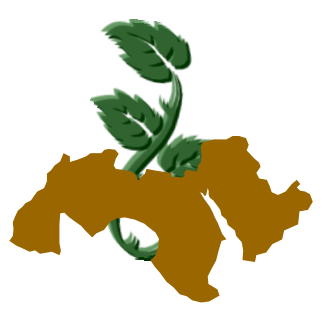

\title{
EFFECT OF MICROWAVE POWER ON QUALITY PARAMETERS OF PECTIN EXTRACTED FROM MANGO PEEL
}

\author{
Assous ${ }^{1}$, M.T.M.; E.S. Abd EI-Wahab ${ }^{1}$ and K.H.M. El-Waseif ${ }^{1}$ \\ 1- Food Technology Research Institute, Agricultural Research Center, Giza, Egypt
}

Keywords: Microwave, Pectin, Mango

\begin{abstract}
The present study aims to use microwave power to facilitate the extraction of pectin from dried mango peels, and also to explore the effect of power on some quality parameters of the resultant pectin. Chemical composition of dried mango peels ascertained a high percent of total pectin, being $16.01 \%$ (on dry weight basis). With respect to microwave heating, the optimal experimented power was $600 \mathrm{~W}$, and 6 minutes as the best short holding time, which gave $12.80 \%$ yield, $86.54 \%$ recovery and $77.20 \%$ anhydrogalacturonic acid (AGA) of extracted pectin. Comparing to the commercial pectin, the results of some physicochemical characterstics of isolated pectin, revealed that the pectin isolated by microwave heating from mango peels, being to some extent analogous to the commercial pectin with respect to its qualities, such as high methoxyl pectin, high degree of estrification (DE), and high percent of AGA besides its high viscosity, followed by the pectin isolated using the conventional method. Statistical analysis of organoleptic data showed no significant differences between strawberry jam prepared by using commercial pectin and that treated with pectin isolated by microwave heating as affecting their texture, color, taste and preference. Besides, high significant differences were detected between various concentrations of added pectin, with respect to the texture alone. Generally, the utilization of pectin isolated from mango peels using microwave heating in jam processing gave high quality attributes resembling that of the commercial pectin when added to strawberry jam and this would also lead to gain economical benefits.
\end{abstract}

\section{INTRODUCTION}

Mango peels are considered as one of the important wastes in fruit juice industry. These wastes usually cause environmental pollution, so technological attempts would be of value to produce valuable nutritional and economical by- products from the discarded peels. The total annual production of mango fruits are 375461 tons produced from 81375 fed of fruitful trees. Ismailia alone produces $33.3 \%$ of the total Egyptian production followed by El-Sharkia Governorate which produces about 29.8\% (Ministry of Agricultural and Land Reclamation, 2004).

Mango peels and stones represent 35 to $60 \%$ of the total fruit weight depending upon the cultivars and the product made therefrom (Larrauri and Cerezal, 1993 and Larrauri et al 1996).

Pectin has become a highly valuable byproduct of fruit juice industry. Pectin, being a natural plant component, has its value not only in food processing, but also in the nutritional and medicinal applications with the great advantage of being legally acceptable. In recent decades, with the increasing emphasis on the favourable functions of pectin in human metabolism, its economical value has increased considerably (Cohn and Cohn, 1996).

Pectin is mainly a linear polymer composed of residues of esterfied galacturonic acid which are linked $\alpha-(1-4)$ axial-axial glycosidic bonds. The precise molecular weight, like that of other polysaccharides, is unknown and there may be as many as 1000 monosaccharide residues per molecule. The amount of esterification of the carboxyl groups of the uronic acid residues, present as methyl ester (Robinson, 1987). 
Pectins are used as gelling agents in jams, and jellies and as a filler or stabilizer in confections, dairy products, fruit preparations, bakery fillings, icings and frostings. Development of pectin-based fat replacers has resulted in a wide range of applications in products such as spread, salad dressing, ice cream (Kalapathy and Proctor, 2001).

The use of suitable method of extraction is of importance during pectin production in order to obtain a good yield of pectin having stable properties. Pectin polysaccharides are of high molecular weight and closely connected with the other polymer components in the cell walls which inhibit their release from the cell matrix. Therefore, processing of the plant material is often applied to facilitate pectin extraction (Kratchanova $\boldsymbol{e t}$ al 2004).

Pectins are commercially produced by acid extraction from citrus peel or apple pomace, followed by filteration and perciptation by 2- propanol (Whistler and BeMiller, 1997). The $\mathrm{pH}$ value, temperature and extraction time have an effect on the yield and quality of pectin. Conventionally, pectin is extracted in acidic solution at about $90^{\circ} \mathrm{C}$ for at least 1 hour, and it was normally a time consuming process. (May, 1990 and Pagan et al 2001)

Sudhakar and Maini (2000) reported that the method for manufacturing pectin from mango peels was standardized by studying various factors that would govern the recovery and quality of pectin. $0.05 \mathrm{M} \mathrm{HCl}$ was found to be the best method of extraction for pectin recovery, giving an optimum pectin yield of about $20.8 \%$ dry wt, bases.

Fishman et al (2006) stated that lime peel pectin extracted by microwave heating was characterized by having high methoxyl pectin with a wide range of molar mass. Panchev et al (1988) used ultrasonic technology to extract apple pectin, and reported that the yield was superior to that obtained by traditional heating extraction.

Wang et al (2005) summarized that microwave power reduced the extraction time and displayed a significantly quardatic effect on the yield of pectin, extracted from dried apple pomace, and the greater yield was obtained when about 499.4 $\mathrm{W}$ of microwave power was selected.

The aim of this work was to study the effect of using microwave heating to extract the pectin from dried mango peels; moreover the effect of addition of the pectin on some properties of processed strawberry jam would be of value.

\section{MATERIALS AND METHODS}

\section{Materials}

Mango (Mangifera indica, L.) peels as by product, were obtained from the production line of Juhayna factories group, $6^{\text {th }}$ October City, Egypt. Commercial pectin MRS-150 SAG (Cesalpinia Food SPA Co.), as citrus pectin, was obtained from the fruit juice factory of Food Tech. Res. Inst., Agric. Res. Center, Egypt. Strawberry fruits and sucrose were purchased from the local market. Citric acid (Sigma Chemical Company) was purchased from El-Gomhoria Medicine and Chemical Company, Egypt.

\section{Methods}

Drying of mango peels: Mango peels were dried in a drying oven at $60^{\circ} \mathrm{C}$ until the moisture content reached to $7.5 \%$.

\section{Extraction of pectin}

Pectin was extracted from mango peels using two methods. The first one is the conventional method which was carried out according to the method of Sudhakar and Maini (2000), where the ratios of dry peel to $0.05 \mathrm{~N} \mathrm{HCl}$ were $1: 10,1$ : 15, 1: 20, 1:25 and 1: $30 \mathrm{w} / \mathrm{v}$. The extraction temperature was $90^{\circ} \mathrm{C}$ in which heating period was $30,60,90$ and 120 min respectively, with continuous stirring whereas the slurry was filtered through cheese cloth. Pectin was precipitated using an equal volume of ethanol $95 \%$ and left for an hour. The precipitated pectin was washed with acidified ethanol $70 \%(0.05 \mathrm{~N} \mathrm{HCl})$, then with $95 \%$ ethanol. The resulted pectin was dried at $60^{\circ} \mathrm{C}$ in a drying oven and pulverized well.

The second method was carried out using multiwave MS-191 MC microwave oven for pectin isolation according to the method of Fishman and Chau, (2000). Mango dry peels were placed in a closed vessel with $0.05 \mathrm{~N}$ HCL at ratio of the most efficient method of pectin extraction of the previous conventionally used at frequency of $2-450$ MHZ with varying intensities of microwave power, which were $90,180,360,600$ and $800 \mathrm{~W}$ of power to study the effect of microwave power on pectin extraction. Different heating time periods 2,4,6,8 and 10 min were used to study the effect of microwave heating period on pectin extraction. The preciptation process and washing were as the previous described in the conventional method 


\section{Manufacturing of strawberry jam}

Approximately $1 \mathrm{~kg}$ of strawberry fruits were mixed with $1.12 \mathrm{~kg}$ sucrose in an open stainless steel pan, then heated and manual stirring were performed. Pectin extracted from mango dry peels with concentrations of $0.1,0.3$ and $0.5 \%$ (pectin /fruit, wt/wt) and $0.35 \%$ commercial pectin (control) were dissolved in a sufficient quantity of distilled water to ensure the complete solubility, then added to the mixture when the total soluble solids reaches $62-65$ Brix. Citric acid was added to the mixture maintaining the $\mathrm{pH}$ value of $3.0 \pm 1$. The mixture was heated till the total soluble solids reached about $68-70$ Brix, and the hot jam was filled into glass jars (volume of $450 \mathrm{ml}$ ), then closed, cooled and stored at room temperature according to the method described by Sulieman (2000).

\section{Analytical Methods}

Moisture content, $\mathrm{pH}$ value, fiber, reducing and total sugars and ash contents were determined according to the methods of A.O.A.C. (2000). Pectin was determined by the method of Lees (1975). Anhydrogalacturonic acid (AGA) was determined by the method of Ranganna (1977). Methoxyl content was determined as described by Owens et al (1952). Degree of estrification (DE), Jelly grade and setting time were determined according to the method of Srirangarajan and Sharikhande (1977).Viscosity was determined using Brookfield viscometer DV3 Ultra programmable Rheometer at $25^{\circ} \mathrm{C} \pm 1{ }^{\circ} \mathrm{C}$, developed by Andon (1987). Yield and recovery of pectin were determined according to Minkov et al (1996) as follows:

$$
\begin{aligned}
& \text { Yield }=\frac{w t . \text { of produced pectin }}{\text { wt. of raw material (used) }} \times 100 \\
& \text { Recovery }=\frac{\text { wt. of produced pectin }}{\text { Pectin wt. of raw material (used) }} \times 100
\end{aligned}
$$

Organoleptic evaluation was determined according to the methods described by Hyvonen and Torma (1983). Texture, color, taste and preference of strawberry jam were evaluated after 24 $\mathrm{hr}$ of processing. Organoleptic evaluation was statistically analyzed by ANOVA procedure of the SPSS statistical package (SPSS, 1990).

\section{RESULTS AND DISCUSSION}

\section{Physico- chemical constituents of dried mango peel}

Some constituents of dried mango peel such as total and reducing sugars, ash, fiber and pectin contents are presented in Table (1). They were $25.80,17.61,3.12,14.44$ and $16.01 \%$ (on dry weight basis), respectively. It is clear that dried mango peel had a high percent of total pectin. Some of these results are in agreement with those reported by Mohamed (2006).

Table 1. Some physio-chemical composition of dried mango peels (on dry wt. basis)

\begin{tabular}{|lc|}
\hline \multicolumn{1}{|c|}{ Properties } & $(\%)$ \\
\hline Moisture content & 7.65 \\
Ash & 3.12 \\
Fiber & 14.44 \\
Pectin & 16.01 \\
Total sugars & 25.80 \\
Reducing sugars & 17.61 \\
Non-reducing sugars & 8.19 \\
\hline
\end{tabular}

Effect of the ratio of solid: liquid and various times on some parameters of pectin isolated by conventional method

Yield, recovery and anhydrogalacturonic acid (AGA) being the main characteristics of pectin isolated from dried mango peel, when using conventional method are shown in Figs. (1 and 2).

The varying ratios of solid: liquid $w / v$, performed during extraction, affected the yield, recovery and AGA are shown in Fig. (1). With increasing the ratio, the increasing of yield, recovery and AGA occurred. From the aforementioned results in the same Fig. (1), it could be seen that the ratio of 1: $20 \mathrm{w} / \mathrm{v}$ solid: liquid and $90 \mathrm{~min}$ could be recommended as holding time and are considered as the optimum conditions to produce quantitative and qualitative mango peel pectin.

Yield of pectin varied between $8.4 \%$ to $11.31 \%$, when $30 \mathrm{~min}$ and $90 \mathrm{~min}$ at $90^{\circ} \mathrm{C}$ of holding time were carried out, using the ratio of $1: 20$ $\mathrm{w} / \mathrm{v}$ of solid : liquid during the extraction process. Whereas, after $120 \mathrm{~min}$ of extraction time, slight 


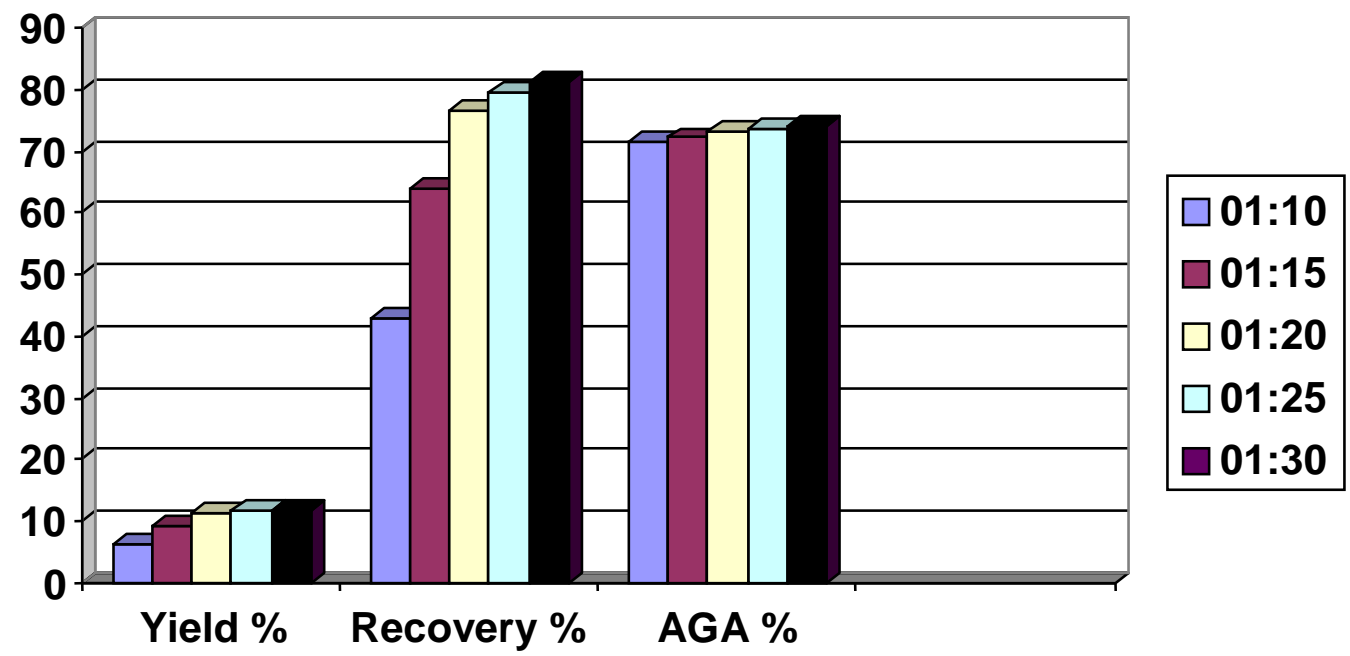

Fig. 1. Effect of varying ratios of solid: liquid on some parameters of pectin extracted at $90^{\circ} \mathrm{C}$ for $90 \mathrm{~min}$.

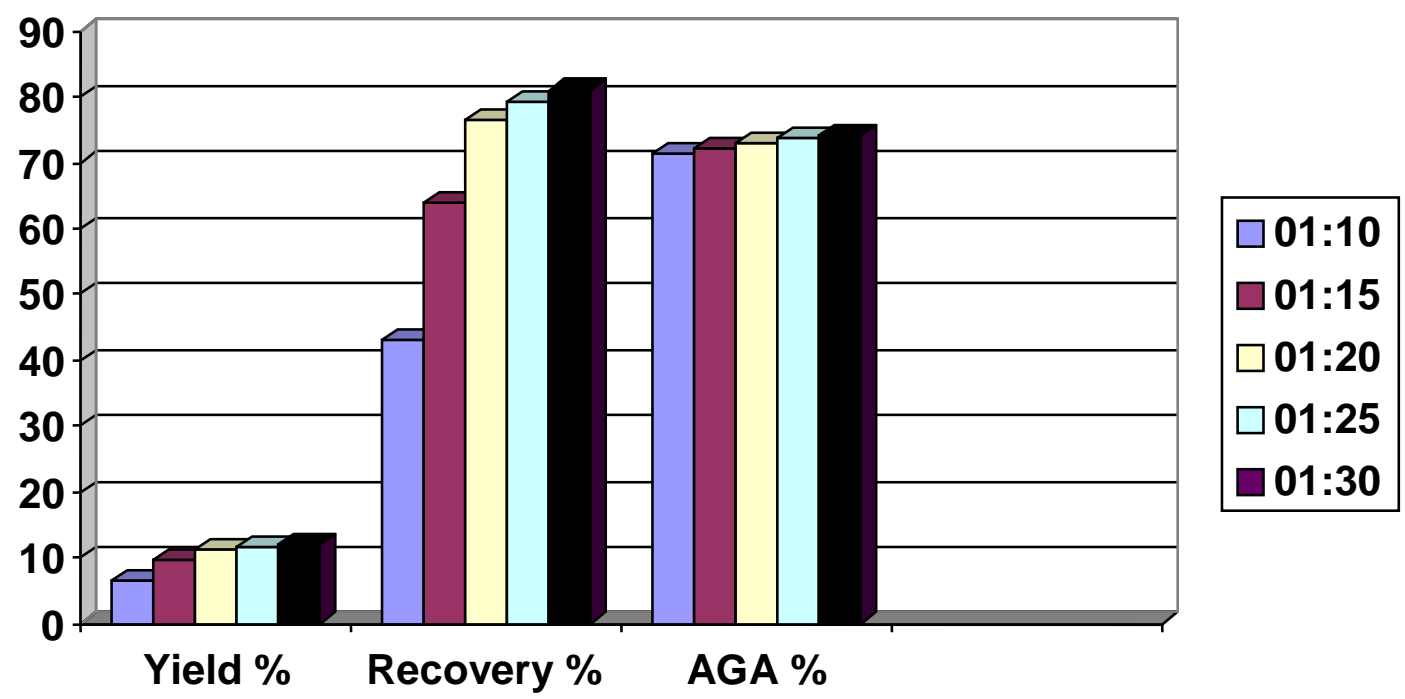

Fig. 2. Effect of varying time at $90^{\circ} \mathrm{C}$ on some parameters of pectin extracted at the ratio of $1: 20 \mathrm{w} / \mathrm{v}$ solid: liquid. 
decrease of yield, recovery and AGA occurred as a result of prolonged time (Fig. 2). These results are in accordance with those found by Fahmy (1999), who reported that, with the increase of extraction time, the reduction of AGA occurred. This means that the optimum time recorded during extraction was 90 min and that gave a high percent of yield, recovery and AGA respectively. Srirangarajan and Sharikhande (1977) found that the pectin yield $13.0 \%$, AGA $61.12 \%$, methoxyl content $8.25 \%$ and $\mathrm{DE} 76 \%$ were in mango peel pectin, extracted at $95^{\circ} \mathrm{C}$. This is in agreement with that mentioned by Kalapathy and Proctor (2001). On the other hand, the results obtained by El-Zoghbi et al (1998) declared that the pectin yield of dried mango peel extracted by $0.02 \mathrm{~N} \mathrm{HCl}$ at $90^{\circ} \mathrm{C}$ for 2 hrs was $25.0 \%$.

Effect of microwave power and holding time on some parameters of isolated pectin

Concerning microwave heating, varying intensity of microwave power and holding time during extraction of mango peel pectin, as estimated conditions of the resulted pectin, are illustrated in Tables (2 and 3).

As shown in Table (2), the optimal power through the experimented multipower procedure was $600 \mathrm{~W}$, which possessed $12.44 \%$ yield, $84.11 \%$ recovery and $77.21 \%$ AGA of the obtained pectin. These results coincided with the results of Wang et al (2005) and Fishman et al (2001). Microwave holding time ranged between 2 to $10 \mathrm{~min}$ within $2 \mathrm{~min}$ intervals. With the increase of holding time, there was an increase in yield, recovery and AGA till 8 min holding time. When $10 \mathrm{~min}$ of microwave holding time was conducted, the decrease of yield, recovery and AGA occurred. From the data obtained in Table (3), it could be noticed that the 6 min holding time was the best short time giving a maximum yield, recovery and AGA of isolated pectin. These findings are in agreement with those found by Kratchanova $\boldsymbol{e t}$ al (1994) and Kratchanova et al (2004), who demonstrated that the pretreatment of the fruit material by microwave heating led to a considerable increase in the yield and the quality of resulted pectin.

\section{Physicho-chemical properties of isolated pectin}

Anhydrogalacturonic acid (AGA) represents $73.04 \%$ and 77.20 of pectin isolated by conventional and microwave heating method compared with the commercial pectin as control which rec- orded $80.21 \%$ (Table 4). Concerning the methox$\mathrm{yl}$ content, the pectin isolated by microwave heating was $9.14 \%$, whereas it was $8.23 \%$ in the traditional one. The data revealed that, the pectin isolated by microwave heating of mango peel, being to some extent analogous to the commercial pectin.

The advantages gained of pectin properties may be resulted from the short holding time and low temperature as low intensity of power during the extraction of mango peel pectin by microwave heating. These results are in accordance with those reported by El-Atawy (1984), who mentioned that methoxyl content of pectin, extracted from beet pulp decreased with increasing the temperature which led to slight decarboxylation of AGA as a result of breaking the ester bond during the extraction process. Concerning the methoxyl content, high methoxyl pectin contains more than $7 \%$ to 12\% methoxyl content Kertesz (1951). This means that the pectin extracted by microwave heating method was classified as high methoxyl pectin.

Table (4) also shows the pectin isolated by microwave heating containing the matter in which the DE was more than the two other pectins, and was higher in its viscosity, which reflects the high quality attributes. From results in Table (4) showed that jelly grade of the extracted pectin using microwave heating, conventional method and commercial pectin were 150, 135 and 150, respectively, and also the setting time ( $\mathrm{min}$ )were 18, 23 and 17, respectively. These results are in accordance with those of Srirangarajan and Sharickhande (1977), EL-Zoghbi et al (1998) and Abdou (2001). The setting time of jelly was $<25 \mathrm{~min}$ indicating it to be a rapid set pectin (Ranganna, 1977).

\section{Role of isolated mango peel pectin on some or-} ganoleptic properties of strawberry jam

Consistency of texture is the main impressive factor of processed strawberry jam, as affected by the addition of some thickening agents such as pectin

Data in Table (5) show that the score of jam texture treated with $0.3 \%$ of conventionally isolated mango peel pectin was $4.01 \pm 0.59$, while it was $4.43 \pm 0.29$ in the case of microwave extracted pectin. When $0.35 \%$ of commercial pectin was added to strawberry jam as control, the texture was $4.53 \pm 0.28$. It is evident that the addition of $0.3 \%$ of both isolated pectins to strawberry jam, 
Table 2. Effect of varying intensity of microwave power of dried mango peel on some parameters of pectin extracted for $4 \mathrm{~min}$. at the ratio of 1: $20 \mathrm{w} / \mathrm{v}$ solid: liquid

\begin{tabular}{|c|c|c|c|}
\hline Microwave power & $\begin{array}{l}\text { Yield } \\
\%\end{array}$ & $\begin{array}{c}\text { Recovery } \\
\%\end{array}$ & $\begin{array}{c}\text { Anhydrogalacturonic } \\
\text { acid \% (AGA) }\end{array}$ \\
\hline 90 & 9.22 & 62.34 & 76.93 \\
\hline 180 & 10.16 & 86.70 & 77.25 \\
\hline 360 & 11.22 & 75.86 & 77.42 \\
\hline 600 & 12.44 & 84.11 & 77.21 \\
\hline 800 & 11.53 & 77.95 & 75.27 \\
\hline
\end{tabular}

Table 3. Effect of varying time at $600 \mathrm{~W}$ of microwave power on some parameters of pectin extracted at the ratio of 1: $20 \mathrm{w} / \mathrm{v}$ solid: liquid

\begin{tabular}{|c|c|c|c|}
\hline $\begin{array}{c}\text { Microwave holding } \\
\text { time (min) }\end{array}$ & $\begin{array}{l}\text { Yield } \\
\%\end{array}$ & $\begin{array}{c}\text { Recovery } \\
\%\end{array}$ & $\begin{array}{c}\text { Anhydrogalacturonic } \\
\text { acid \% (AGA) }\end{array}$ \\
\hline 2 & 9.57 & 64.71 & 76.05 \\
\hline 4 & 12.44 & 84.11 & 77.21 \\
\hline 6 & 12.80 & 86.54 & 77.20 \\
\hline 8 & 13.03 & 88.10 & 77.00 \\
\hline 10 & 12.72 & 86.00 & 76.85 \\
\hline
\end{tabular}

Table 4. Some physico-chemical constituents of mango peel pectin.

\begin{tabular}{|lccc|}
\hline \multirow{2}{*}{ Constituents } & \multicolumn{2}{c}{ Extracted by } & Commercial \\
\cline { 2 - 3 } & $\begin{array}{c}\text { Conventional } \\
\text { method }\end{array}$ & $\begin{array}{c}\text { Microwave } \\
\text { heating }\end{array}$ & pectin \\
\hline Moisture content \% & 8.32 & 7.84 & 9.63 \\
pH value & 3.33 & 3.28 & 3.15 \\
Viscosity (cp) & 150 & 165 & 168 \\
Ash \% & 3.12 & 3.22 & 2.58 \\
Anhydrogalacturonic acid \% & 73.04 & 77.20 & 80.21 \\
Methoxyl content \% & 8.23 & 9.14 & 9.42 \\
Degree of estrification\% & 63.97 & 67.21 & 66.84 \\
Gelly grade & 135 & 150 & 150 \\
Setting time (min) & 23 & 18 & 17 \\
\hline
\end{tabular}


Table 5. Sensory evaluation of strawberry jam containing various concentrations of pectin.

\begin{tabular}{|ccccc|}
\hline Parameters & $\begin{array}{c}(5) \\
\text { Texture } \\
\text { Mean } \pm \text { S.D. }\end{array}$ & $\begin{array}{c}(5) \\
\text { Taste } \\
\text { Mean } \pm \text { S.D. }\end{array}$ & $\begin{array}{c}(5) \\
\text { Color } \\
\text { Mean } \pm \text { S.D. }\end{array}$ & $\begin{array}{c}(5) \\
\text { Preference } \\
\text { Mean } \pm \text { S.D. }\end{array}$ \\
\hline $\begin{array}{c}\text { Commercial pectin } \\
0.35 \%\end{array}$ & $4.53 \pm 0.28^{\mathrm{a}}$ & $4.69 \pm 0.25^{\mathrm{a}}$ & $4.62 \pm 0.21^{\mathrm{ab}}$ & $4.60 \pm 0.24^{\mathrm{a}}$ \\
$\begin{array}{c}\text { Pectin extracted by } \\
\text { Conventional method }\end{array}$ & $3.58 \pm 0.44^{\mathrm{c}}$ & $4.30 \pm 0.47^{\mathrm{b}}$ & $4.33 \pm 0.41^{\mathrm{b}}$ & $4.03 \pm 0.52^{\mathrm{b}}$ \\
$0.1 \%$ & $4.01 \pm 0.59^{\mathrm{a}}$ & $4.52 \pm 0.44^{\mathrm{ab}}$ & $4.51 \pm 0.17^{\mathrm{ab}}$ & $4.18 \pm 0.31^{\mathrm{ab}}$ \\
$0.3 \%$ & $4.51 \pm 0.28^{\mathrm{a}}$ & $4.57 \pm 0.22^{\mathrm{a}}$ & $4.56 \pm 0.33^{\mathrm{ab}}$ & $4.55 \pm 0.33^{\mathrm{a}}$ \\
$0.5 \%$ & & & & \\
Pectin extracted by & & & & \\
Microwave heating & & & & \\
$0.1 \%$ & $3.73 \pm 0.43^{\mathrm{bc}}$ & $4.53 \pm 0.26^{\mathrm{ab}}$ & $4.40 \pm 0.33^{\mathrm{ab}}$ & $4.25 \pm 0.59^{\mathrm{ab}}$ \\
$0.3 \%$ & $4.43 \pm 0.29^{\mathrm{a}}$ & $4.67 \pm 0.20^{\mathrm{a}}$ & $4.57 \pm 0.28^{\mathrm{ab}}$ & $4.56 \pm 0.47^{\mathrm{a}}$ \\
$0.5 \%$ & $4.52 \pm 0.29^{\mathrm{a}}$ & $4.73 \pm 0.19^{\mathrm{a}}$ & $4.65 \pm 0.34^{\mathrm{a}}$ & $4.59 \pm 0.36^{\mathrm{a}}$ \\
\hline F. value & $10.92^{* *}$ & $2.47^{*}$ & $1.89 \mathrm{NS}^{\mathrm{a}}$ & $3.14^{*}$ \\
\hline
\end{tabular}

S.D $=$ Standard Deviation $\mathrm{p}^{*}<0.05, \quad \mathrm{p}^{* *}<0.01$

N.S $=$ Non Significant

gave an accepted texture, color, taste and preference, and that being in accordance with the standard additives of commercial pectin.

Statistical analysis ascertained no significant differences between strawberry jam prepared by using commercial pectin and that treated with pectin isolated by microwave heating in their texture, color, taste and preference, especially at the concentration of $0.3 \%$ added pectin. On the other hand, there were significant differences existing between the jam prepared by $0.1 \%$ of both added pectin and that prepared by the addition of $0.3 \%$ of both isolated pectin, and also the commercial one. Highly significant differences were found between various concentrations of added pectin, with respect to the texture alone.

From the aforementioned results, it could be concluded that the pectin isolated from mango peel by the microwave heating method surpassed in its quality over the already conventional method. Utilization of this pectin in jam processing, gave high quality attributes resembling that found when commercial pectin was used, and also achieved economical benefits.

\section{REFERENCES}

Abdou, S.A.H. (2001). Technological, PhysicoChemical an Biological Studies on Fruit and Kernels of Mango. pp. 170-173. Ph.D. Thesis, Food Sci. and Technol. Dept., Fac. of Agric., Cairo Univ., Egypt.

Andon, S.A. (1987). Application of soluble dietary fiber. Food Technol. 41: 70- 74

A.O.A.C. (2000). Official Methods of Analysis of the Association of Official Analytical Chemists International. Published by the Association of Official Analytical Chemist's International. Maryland 20877-2417. USA.

Cohn, R. and A.L. Cohn (1996). The by- products of fruit processing. In: Arthey, D. and Ashurst, P.R. (eds.), Fruit Processing, $1^{\text {st }}$ Ed., pp. 196-218. Chapman and Hall, London ,UK.

El-Atawy, Y.S. (1984). Study on Pectin Production From some By-product of Food Factories. p. 118. M.Sc. Thesis. Dept of Food Sci., Fac. of Agric. (Moshtohor),Zagzig Univ., Egypt.

El-Zoghbi, M.; F.B. Badr, and F.M. Hassan, (1998). Extraction of pectin from some fruit wastes. Egypt J. Appl. Sci. 13(7): 238 -256. 
Fahmy. A.H. (1999). Preparation of Low Methoxyl Pectin from Some Citrus Processing Wastes. pp. 90-102. Ph.D. Thesis, Dept. of Food Sci., Fac. of Agric., Cairo Univ., Egypt.

Fishman, M.L. and H.K. Chau (2000). Extraction of pectin by microwave heating under pressure. United States Patent 6, 143: 337.

Fishman, M.L.; H.K. Chau; F. Kolpak and J. Brady (2001). Solvent effects on the molecular properties of pectins. J. Agric. and Food Chem. 49: 4494 - 4501.

Fishman, M.L.; H.K. Chau; P.D. Hoagland; A.T. Hotchkiss (2006). Microwave - assisted extraction of lime pectin. Food Hydrocolloids (1): 1-8.

Hyvonen, L. and R. Torma (1983). Examination of sugar, Sugar alcohols and artificial sweeteners as substitutes for sucrose in strawberry jam product development, J. Food Sci. 48: 183.

Kalapathy, U. and A. Proctor (2001). Effect of acid extraction and alcohol precipitation conditions on the yield and purity of soy hull pectin. Food Chem. 73: 393 - 396.

Kertesz, Z. (1951). The Pectic Substances. p. 235. Interscience Publishers Inc., New York.

Kratchanova, M.; I. Panchev; E. Pavlova, and L. Shtereva (1994). Extraction of pectin from fruit materials pretreated in an electromagnetit field of super-high frequency, Carbohydrate Polymers 25: 141 - 144.

Kratchanova, M.; E. Pavlova and I. Panchev (2004). The effect of microwave heating of fresh orange peels on the fruit tissue and quality of extracted pectin. Carbohydrate Polymers 56: 181 185.

Larrauri, J.A.; P. Cerezal (1993). Characterization de los residues de diferentes variedades de mango. Alimentaria 242: 89 - 92.

Larrauri, J.A.; P. Ruperez; B. Borroto and F. Saura (1996). Mango peels as a new tropical fiber: Preparation and Characterization. Lebensim Wiss. U. - Technol. 29: 729 - 733.

Lees, R. (1975). Food Analysis: Analytical and Quality Control Methods for the Food Manufacturer and Buyer. $3^{\text {rd }}$ Section II- P1. Laboratory Handbook of Methods of Food Analysis, Lenoard Hill Books Publisher, London.

May, D. (1990). Industrial pectins, Source, Production and application. Carbohydrate Polymers 12: $79-84$.

Ministry of Agricultural and Land Reclamation (2004). Area, Yield and Production of Fruits. 331-332. Economic Affairs Sector, Min. Agric., \& Land Reclamation, Dokki, Cairo, Egypt.
Minkov, S.; A. Minchev, and K. Paev (1996). Modelling of the hydrolysis and extraction of apple pectin. J. Food Engineering 29: 107 - 113. Mohamed, M.Z. (2006). Studies on Utilization of Food Processing Wastes. p. 63. M.Sc. Thesis, Dept. of Food Sci., Fac. of Agric., Mansoura Univ., Egypt .

Owens, H.S.; R.M. McCready; A.D. Schephered; T.H. Schulz; E.L. Pippen; H.A. Wenson; J.C.J. Miers ; R.F. Erlandsen and W.D. Maclay (1952). Methods used at western regional research laboratory for extraction and analysis of pectin materials. USDA Bur. Agric. Ind. Chem. Report No. 340, pp. 24

Pagan, J.; A. Ibarz; M.L. Lorca; A. Pagan and G.V. Barbosa (2001). Extraction and characterization of pectin from stored peach pomace. Food Research International 34: 605 - 612 .

Panchev, I. N.; N.A. Kirtchev and C. Krachanova (1988). Improving pectin technology. II. Extraction using Ultrasonic treatment. Int. J. Food Sci, and Technol. pp. 337 - 341.

Ranganna, S. (1977). Manual of Analysis of Fruit and Vegetable Products. pp. 21-54. Tata McGraw-Hill Publishing Company Limited, New Delhi.

Robinson, D.S. (1987). Food Biochemistry and NutritionaValue. pp. 84-86. Longman Scientific and Technical, John Wiley and Sons, Inc., New York.

SPSS (1990). SPSS /PC for the IBM PC/XI. Chicago, IL. USA.

Srirangarajan, A.N. and A. Sharickhande (1977). Characterization of mango peel pectin. J. Food Sci. 42: 279 - 280.

Sudhakar- Rao- D.V. and S.B. Maini (2000). Isolation and characterization of mango peel pectin. J. Food Processing and Preservation 24(3): $209-227$.

Sulieman, A.M. (2000). Studies on Food Wastes. p. 47. Ph.D. Thesis, Dept. of Food Science, Fac. of Agric., Zagazig Univ., Egypt.

Wang, S.; F. Chen; J. Wu; Z. Wang; X. Liao; and $\mathrm{X}$. Hu (2005). Optimization of pectin extraction assisted by microwave from apple pomace using response surface methodology. J. of Food Engineering 11: 1- 8.

Whistler, R.L. and J.N.Be Miller (1997). Pectins. In: Carbohydrate Chemistry for Food Scientists. pp. 203-210. Eagan Press, St. Paul, MN. 